\title{
Disappearance: A Backwards Waltz
}

A place for cars, that's where

I think I must be now, a world with so many

gasses and deliveries, and we are going

there again. Walking back to a renamed home.

The words are melancholic but don't be fooled.

I stick my long finger

into the button marked cross

and I cross. Direction might be infallible

and feet accept the future as they march. I cross

onto the left-behind grit, and this is also

my home now, the streets that rise to greet me. A car, as I walk slow, honks disapproval. My life in place has disappeared. Like the houses

on 55th Street, the big old colonial

and the spidery A-frame next door, our neighbors

in dust. Trees went up to the curb where sometimes the cars were parked, and sometimes, often at dusk, we would be playing. Up and down the porch steps

in scissors steps, and I remember

that I didn't have to look very far. I guess it's

important to accept accident: the birth

of an unrequested day, some ecstasy of stumbling, and even, when friends take it back, initial love. 